\title{
ANALISIS BENTUK DAN FAKTOR PENYEBAB PERUBAHAN MAKNA PEYORASI DAN AMELIORASI DALAM BERITA KRIMINAL
}

\author{
Ketriyawati \\ Institut Agama Islam Negeri Syekh Nurjati Cirebon \\ email: Ketriyawati8@gmail.com
}

\begin{abstract}
(Title: Form Analysis and Factors That Cause Changes in Peyoration and Amelioration Meanings in Criminal News). This study aims to analyze the changes in the meaning of peyoration and amelioration and the causes of changes in their meaning in the criminal news of the Radar Cirebon newspaper in January 2019 edition. The research method used in this study is a qualitative method. Based on the data and results of the analysis, it can be concluded that the forms and changes in the meaning of the exploration and amelioration are in the form of words and phrases. Factors causing changes in the meaning of exploration and amelioration are factors of socio-cultural development, differences in usage fields, the existence of associations, and differences in responses. The results of the study can be used to develop class X Indonesian language subject matter in odd semseter with basic competence 3.15 analyzing aspects of meaning and language in biographies. In addition, research results can be a source of inspiration for journalists to be better in the selection and use of diction in writing criminal news. Hopefully, criminal news presented in the mass media, especially newspapers, is increasingly interesting by using variations in language and paying attention to the meaning contained therein.
\end{abstract}

Keyword: change of meaning, exploration, amelioration, variety of journalism, criminal news

\section{PENDAHULUAN}

Perubahan makna termasuk dalam kajian ilmu semantik. Menurut Lyons (via Pateda, 2010: 82), semantik merupakan ilmu yang mengkaji makna. Termasuk juga perubahan makna di dalamnya. Pada kajian semantik, terdapat pembahasan tentang perubahan makna atau disebut juga dengan pergeseran makna. Chaer (2013: 130) mengungkapkan bahwa secara sinkronis, makna sebuah kata dapat berubah. Akan tetapi, secara diakronis tidak semua kata maknanya akan berubah. Makna tersebut berupa satuan lingual, baik makna leksikal maupun makna gramatikal.

Tarigan (2009: 77-78) menyebutkan bahwa jenis-jenis dari perubahan makna sebagai berikut. Pertama, generalisasi atau perluasan adalah proses perubahan makna kata dari yang lebih khusus kepada yang lebih umum atau dari yang lebih sempit ke yang lebih luas. Kedua, spesialisasi atau pengkhususan mengacu kepada suatu perubahan yang mengakibatkan makna kata menjadi lebih khusus atau lebih sempit dalam penggunaannya. Ketiga, amelio- rasi adalah proses perubahan makna kata kepada tingkat yang lebih tinggi atau makna baru yang dianggap lebih lebih baik daripada makna sebelumnya. Peninggian makna atau ameliorasi merupakan suatu proses perubahan makna di mana makna akan menjadi lebih tinggi, lebih hormat, dan lebih baik nilainya daripada makna sebelumnya. Peninggian dalam kata pada umumnya terjadi bertujuan untuk memberikan penghargaan dan penghormatan kepada objek tertentu melalui suatu kata.

Menurut Ulman (via Shinta, 2010: 74), hal tersebut dapat mengarahkan makna lebih ke arah positif. Misalnya, kata ceramah yang semula berarti suka bercakap-cakap, cerewet, banyak mencela, kemudian mengalami perubahan makna yang bersifat positif. Seperti halnya dengan pidato tentang suatu ilmu, agama, atau yang lainnya. Selain itu, makna kata-kata yang bersifat netral sering mengarah kepada makna positif bukan negatif. Misalnya kata nasib atau takdir yang dapat mengarah ke peyorasi atau ameliorasi tergantung konteks. 
Peyorasi adalah proses perubahan makna kata kepada tingkat yang lebih rendah atau makna baru yang dianggap lebih jelek atau lebih buruk dari makna yang sebelumnya. Penurunan makna atau peyorasi mengakibatkan makna baru atau makna yang sedang dirasakan lebih rendah, kurang menyenangkan, dan kurang halus nilainya daripada makna sebelumnya (lama). Pada umumnya, penggunaan kata-kata yang cenderung ke arah peyorasi merupakan bentuk kata-kata tabu. Misalnya tentang penyakit, seks, kejahatan, dan sebagainya. Misalnya kata penjara mengalami peyorasi menjadi lembaga pemasyarakatan.

Sinestesia adalah perubahan makna yang terjadi akibat pertukaran tanggapan antara dua pancar indera berbeda.Asosiasi adalah perubahan makna yang terjadi akibat persamaan sifat.

Teori jenis-jenis perubahan makna tersebutlah yang akan menjadi pembatas dalam pengklasifikasian data yang mengalami perubahan makna peyorasi dan ameliorasi dalam penelitian ini.

Terjadinya perubahan makna dapat dipengaruhi oleh beberapa faktor, Suwandi (via Kustriyono, 2016: 17-18), mengemukakan 12 faktor penyebab terjadinya perubahan makna. Pertama, faktor linguistik, perubahan makna karena faktor linguistik berkaitan erat dengan fonologi, morfologi, dan sintaksis. Kedua, faktor kesejarahan, berhubungan dengan perkembangan leksem. Ketiga, faktor sosial masyarakat, berhubungan dengan perkembangan leksem di dalam masyarakat. Keempat, faktor psikologis, disebabkan oleh keadaan psikologis seperti rasa takut, menjaga perasaan, dan sebagainya. Kelima, faktor kebutuhan kata baru, berhubungan erat dengan kebutuhan masyarakat pemakai bahasa. Keenam, faktor perkembangan ilmu dan teknologi. Ketujuh, faktor perbedaan bidang pemakaian lingkungan. Kedelapan, faktor pengaruh bahasa asing, disebabkan oleh pengaruh bahasa asing yang berupa peminjaman makna. Kesembilan, faktor asosiasi, kata-kata masih ada hubungannya dengan makna kata tersebut pada bidang asalnya. Kesepuluh, faktor pertukaran tanggapan indera berhubungan dengan indera manusia yaitu mata, telinga, hidung, lidah dan kulit. Kesebelas, faktor perbedaan tanggapan pemakaian bahasa, sejumlah kata yang digunakan oleh pemakainya tidaklah mempunyai nilai sama. Keduabelas faktor penyingkatan. Dari teori faktor penyebab perubahan makna inilah faktor perubahan makna dari data yang ditemukan akan diketahui faktor penyebab perubahan maknanya.

Berdasarkan hasil analisis perubahan makna peyorasi dan ameliorasi dalam berita krimnal pada surat kabar Radar Cirebon edisi Januari 2019, bentuk peyorasi dan ameliorasi sangat beragam dan mendominasi. Hal tersebut dikarenakan teks berita kriminal merupakan berita tentang kejahatan, seperti halnya penipuan, pembunuhan pencopetan, pemerkosaan, pencurian, narkoba, perampokan, penganiayaan, tawuran, dan sebagainya yang melanggar hukum (Dewi, 2013: 155). Dalam penulisannya banyak menggunakan bentuk perubahan makna peyorasi dan ameliorasi. Hal tersebut tergantung bagaimana wartawan membahasakan beritanya.

\section{METODE}

Pendekatan yang digunakan dalam penelitian ini adalah pendekatan kualitatif. Bogdan dan Taylor (via Moleong, 2013: 4), mendefinisikan bahwa metode kualitatif merupakan prosedur penelitian yang menghasilkan data deskriptif berupa kata-kata tertulis atau lisan. Sementara itu, metode pengumpulan data yang digunakan adalah metode dokumentasi dan metode simak. Adapun instrumen yang digunakan untuk pengumpulan data yaitu peneliti sendiri (human instrumen) yang memfokuskan penelitian, memilih berita sebagai sumber data, mengumpulkan data, menilai kualitas data, menganalisis data, menafsirkan data, dan membuat simpulan hasil temuan dari sumber penelitian yang berupa surat kabar Radar Cirebon edisi Januari 2019.

Teknik analisis data dalam penelitian ini menggunakan metode agih. Menurut Sudaryanto (via Hasanah, 2018: 100), metode agih adalah metode analisis data yang alat penentunya merupakan bagian dari bahasa yang bersangkutan itu sendiri. Untuk membuat inferensi yang valid dari teks berita, digunakan analisis data Miles dan Huberman. Dalam- 
menganalisis data menurut Miles dan Huberman (via Sugiyono, 2014: 91) harus interakti dan bersinambung sampai jenuh. Dalam hal ini, teknik analisis yang dilakukan dengan cara (1) seleksi data, (2) mengklasifikasikan bentuk perubahan makna dengan menggunakan teknik ganti (substiusi), (3) menentukan fungsi perubahan makna.

\section{HASIL DAN PEMBAHASAN Hasil}

Data penelitian bersumber dari berita kriminal yang berasal dari surat kabar Radar Cirebon edisi Januari 2019. Hasil analisis dari 42 berita kiriminal edisi Januari 2019, diperoleh 43 bentuk kata dan 9 bentuk frasa yang mengalami perubahan makna. Dari 43 kata yang mengalami perubahan makna, sejumlah 23 kata mengalami perubahan makna peyorasi dan sebanyak 20 lainnya mengalami perubahan makna ameliorasi. Sementara itu, dari 9 frasa, sebanyak 2 frasa mengalami perubahan makna peyorasi dan sejumlah 7 frasa lainnya mengalami perubahan makna ameliorasi. Selain itu, diketahui faktor penyebab dari perubahan makna peyorasi dan ameliorasi tersebut meliputi faktor perkembangan sosial dan budaya, perbedaan bidang pemakaian, adanya asosiasi, serta perbedaan tanggapan.

Bentuk dari perubahan makna peyorasi dan ameliorasi meliputi bentuk kata dan frasa. Berikut klasifikasi bentuk kata dan frasa yang mengalami perubahan makna tersebut.

Dari 43 kata yang mengalami perubahan makna, sebanyak 23 kata mengalami bentuk perubahan makna peyorasi dan sebanyak 20 kata lainnya mengalami perubahan makna ameliorasi. Data tersebut disajikan dalam Tabel 1 .

Dari 9 frasa yang mengalami perubahan makna, sebanyak 2 frasa mengalami perubahan makna bentuk peyorasi dan sebanyak 7 frasa lainnya mengalami perubahan makna bentuk ameliorasi. Data tersebut akan disajikan dalam Tabel 2.

\section{Faktor Penyebab Perubahan Makna}

Faktor penyebab perubahan makna dari 43 kata dan 9 frasa meliputi faktor perkembangan sosial dan budaya, perbedaan bidang pemakaian, adanya asosiasi, dan perbedaan tanggapan, disajikan dalam Tabel 4.

Tabel 1. Rekapitulasi Jumlah Kata yang Mengalami Bentuk Perubahan Makna

\begin{tabular}{|c|c|c|c|}
\hline No. & Perubahan Makna & Kata & Jumlah \\
\hline 1 & Peyorasi & $\begin{array}{l}\text { dibekuk, raib, terciduk, digelandang, disiksa, bui, gondol, } \\
\text { diciduk, tersandung, mayat, sikat, disergap, digasak, } \\
\text { terendus, komplotan, diderita, menjatuhkan, embat, diamuk, } \\
\text { terjaring, lenyap, ringkus, pesakitan, }\end{array}$ & 23 \\
\hline 2. & Ameliorasi & $\begin{array}{l}\text { diamankan, mengamankan, dikerjai, wanita, kupu-kupu, } \\
\text { kawanan, diambil, habisi, jenazah, duka, menghabisi, } \\
\text { diperiksa, mencari, mengambil, pendalaman, mendalami, } \\
\text { pria, menyangkal, rehabilitas, ngamar }\end{array}$ & 20 \\
\hline \multicolumn{2}{|r|}{ Total } & & 43 \\
\hline
\end{tabular}

Tabel 2. Rekapitulasi Jumlah Frasa yang Mengalami Perubahan Makna

\begin{tabular}{cccc}
\hline No. & Makna & Frasa & Jumlah \\
\hline 1. & Peyorasi & bogem mentah, menekan angka & 2 \\
2. & Ameliorasi & $\begin{array}{l}\text { harta berharga, pahlawan devisa, di balik jeruji, punya } \\
\text { hubungan, hubungan gelap, aliran dana, dibawa kabur }\end{array}$ & 7 \\
\hline Total & 9 & \\
\hline
\end{tabular}


Tabel 4. Rekapitulasi Jumlah Faktor Penyebab Perubahan Makna

\begin{tabular}{|c|c|c|c|c|c|}
\hline No. & Faktor Penyebab & Bentuk Kata & Jumlah & Bentuk Frasa & Jumlah \\
\hline 1. & $\begin{array}{l}\text { Perkembangan } \\
\text { sosial dan budaya }\end{array}$ & $\begin{array}{l}\text { Pria } \\
\text { Wanita }\end{array}$ & 2 & & \\
\hline 2. & $\begin{array}{l}\text { Perbedaan } \\
\text { bidang pemakaian }\end{array}$ & Diperiksa & 1 & & \\
\hline 3. & Adanya asosiasi & ngamar, kupu-kupu & 2 & $\begin{array}{l}\text { pahlawan devisa, } \\
\text { dibalik jeruji, } \\
\text { hubungan gelap, } \\
\text { aliran dana, } \\
\text { dibawa kabur, } \\
\text { memiliki-hubungan, } \\
\text { harta berharga, }\end{array}$ & 7 \\
\hline 4. & $\begin{array}{l}\text { Perbedaan } \\
\text { tanggapan }\end{array}$ & $\begin{array}{l}\text { dibekuk, diamankan, } \\
\text { mengamankan, menghabisi, } \\
\text { dikerjai, raib, terciduk, } \\
\text { digelandang, disiksa, bui, } \\
\text { gondol, kawanan, diciduk, } \\
\text { diambil, mayat tersandung, } \\
\text { jenazah, duka, sikat, mencari, } \\
\text { mengambil, digasak, komplotan, } \\
\text { terendus, mendalam, diderita, } \\
\text { menjatuhkan, embat, diamuk, } \\
\text { menyangkal, pendalaman, } \\
\text { rehabilitas, terjaring, lenyap, } \\
\text { ringkus, pesakitan }\end{array}$ & 37 & $\begin{array}{l}\text { menekan angka, } \\
\text { bogem mentah }\end{array}$ & 2 \\
\hline & Total & & 42 & & 9 \\
\hline
\end{tabular}

\section{Pembahasan}

\section{Perubahan Makna Peyorasi dan Ameliorasi}

Pertama, kata yang mengalami perubahan makna peyorasi. Perubahan makna peyorasi tampak pada contoh-contoh kalimat sebagai berikut.

(14) Tiga hari penyelidikan, akhirnya jejak keberadaan pelaku terendus.

Kalimat (14) terdapat dalam berita yang berjudul Beli Ninja dan Foya-foya, yang terbit pada 18 Januari 2019. Kata terendus dalam kalimat tersebut, telah mengalami perubahan makna peyorasi. Kata terendus dalam KBBI berarti 'tercium'. Akan tetapi, berdasarkan konteks kalimatnya, kata terendus diartikan sebagai diketahui. Kata terendus memiliki nilai rasa lebih buruk dari kata diketahui. Hal tersebut dikarenakan kata terendus memiliki konotasi tidak baik yang mengarah pada kono- tasi tidak pantas untuk digunakan. Hal tersebut dikarenakan penggunaan kata endus diperuntukkan untuk binatang, bukan manusia.

\section{(19) Pelaku Curanmor Diamuk Massa.}

Kalimat (19) terdapat dalam berita yang berjudul Pelaku Curanmor Diamuk Mas$s a$, yang terbit pada 25 Januari 2019. Kata diamuk dalam kalimat tersebut, telah mengalami perubahan makna peyorasi. Kata diamuk merupakan sinonim dari kata dihakimi. Kata dihakimi yang telah mengalami perluasan makna dalam KBBI berarti 'diadili'. Kata diamuk memiliki nilai lebih buruk dari kata dihakimi. Hal tersebut dikarenakan kata diamuk dalam penggunaannya diperuntukkan untuk binatang bukan manusia. Seperti halnya kerbau yang mengamuk, banteng yang mengamuk, dan lainnya. 
(23) Dari kasus ini baru sunjaya dan gatot yang akhirnya jadi pesakitan.

Kalimat (23) di atas, terdapat dalam berita yang berjudul Sunjaya Diperiksa Sebagai Tersangka, yang terbit pada 31 Januari 2019. Kata pesakitan dalam kalimat tersebut telah mengalami perubahan makna peyorasi. Kata pesakitan dalam kalimat tersebut dapat diartikan juga sebagai pelaku. Hal tersebut dapat diketahui berdasarkan konteks kalimatnya. Dalam berita, diungkap lanjutan dari kasus dugaan suap, mutasi jabatan, free proyek dan perizinan yang menjerat Sunjaya. Setelah penyidik KPK melakukan pemeriksaan terhada 48 orang yang terdiri dari PNS dan pihak swasta di Mapolres Cirebon Kota kemarin, barulah kemudian KPK mentapkan Sunjaya dan Gatot menjadi pesakitan dalam kasus ini. Sunjaya ditetapkan sebagai penerima suap dan Gatot ditetapkan sebagai pemberi suap untuk mendapatkan kursi jabatan sebagai sekretaris Dinas PUPR.

Kata pesakitan dalam KBBI berarti 'terdakwa'. Itu artinya, kata pesakian merupakan sinonim dari kata pelaku. Walaupun pesakitan dan pelaku memiliki makna yang sama, akan tetapi keduanya memiliki nilai rasa yang berbeda. Kata pesakitan memiliki nilai rasa lebih buruk dari kata pelaku. Hal tersebut dikarenakan kata pesakitan merujuk pada situasi di mana seseorang benar-benar dalam keadaan kesakitan, padahal nyatanya mereka hanya ditetapkan sebagai pelaku atas kasus yang menjerat mereka.

Kedua, kata yang mengalami perubahan makna ameliorasi. Perubahan makna ameliorasi tampak pada contoh-contoh kalimat sebagai berikut.

(25) KPK berhasil mengamankan sejumlah dokumen, sebuah laptop dan dua buah CPU.

Kalimat (25) terdapat dalam berita yang berjudul KPK: Korupsi Proyek SPAM Sudah Sistematis, yang terbit pada 3 Januari 2019. Kata mengamankan dalam kalimat tersebut, mengalami perubahan makna ameliorasi. Kata mengamankan dalam KBBI berarti 'menjadikan tidak berbahaya; tidak rusuh'. Akan tetapi, kata mengamankan dalam kalimat tersebut diartikan sebagai menyita. Hal tersebut diketahui berdasarkan konteks kalimatnya. Dalam berita, diungkap peristiwa penggeledahan yang dilakukan oleh KPK di sejumlah lokasi terkait kasus dugaan proyek SPAM Kementrian Pekerjaan Umum dan Perumahan Rakyat (PURP). Dari aksi penggeledahan tersebut, tim penyidik mengamankan sejumah dokumen terkait proyek SPAM di berbagai daerah di Indonesia. Juru bicara KPK, Febry menjelaskan bahwa tindakan tersebut merupakan lanjutan dari penggeledahan di Kantor SPAM Kementrian PUPR yang telah dilakukan sebelumnya.

Dari konteks berita tersebut, dapat diketahui bahwa maksud dari kata mengamankan tersebut adalah menyita. Menurut KBBI, kata menyita berarti 'mengambil dan menahan barang, dilakukan oleh alat negara sesuai dengan putusan hakim'. Kata mengamankan memiliki nilai rasa yang lebih baik dibandingkan dengan kata menyita. Hal tersebut dikarenakan mengamankan lebih dianggap suatu perbuatan yang dilakukan untuk kebaikan dan mengambil dengan diserta izin. Berbeda dengan perbuatan menyita yang dalam pelaksanaanya terdapat unsur paksaan dan semena-mena.

\section{(26) "Dikerjai" Pedagang Pasar Malam}

Kalimat (26) terdapat dalam berita yang berjudul "Dikerjai" Pedagang Pasar Malam, yang terbit pada 4 Januari 2019. Kata dikerjai dalam kalimat tersebut, telah mengalami perubahan makna ameliorasi. Berdasarkan konteks kalimatnya, kata dikerjai dalam kalimat tersebut diartikan sebagai diperkosa. Hal tersebut dapat diketahui dari peristiwa pemerkosaan yang diungkap dalam berita. Berita tersebut mengungkap tentang seorang gadis yang berinisial ED (16) asal Kecamatan Panguragan Kabupaten Cirebon yang diperkosa oleh penjual sandal berinisial RS di Pasar Malam Palimanan pada Rabu (12/12). Sebelum peristiwa tersebut terjadi, pada Selasa (11/12) korban pergi ke pasar malam yang berada di Alun-alun Palimanan. Pada saat itulah korban diajak berkenalan oleh pelaku, yang merupakan penjual sandal di pasar malam tersebut. Singkat cerita, pelaku menawarkan diri untuk mengantar pulang sang korban ke kosannya. 
Korban tidak menolak untuk diantar pulang oleh pelaku saat itu.

Besoknya, pada Rabu (12/12) korban pergi ke pasar malam Palimanan lagi untuk membeli ketoprak. Saat itulah korban bertemu kembali dengan pelaku. Pelaku yang memiliki ketetarikan pada korban pun mengajak korban berpacaran. Namun korban menolak dengan alasan mereka baru kenal. Seperti malam sebelumnya, pelaku kembali mengantar korban pulang ke kosannya. Sesampainya di kosan, pelaku tak langsung pulang dengan alasan ingin berbagi makanan dan menikmati malam dengan korban. Di tengah obrolan, tiba-tiba palaku mengajak korban untuk bersetubuh. Sontak, korban pun langsung menolak ajakan tersebut. Karena korban menolak, akhirnya pelaku memperkosa korban di kamar kostnya.

Setelah kejadian tersebut, RS yang ketagihan pun berulangkali terus menyambangi kosan korban. Korban yang merasa ketakutan pun melapor ke RT setempat dan kepada kakaknya. Barulah pada Sabtu (15/12), korban dan kelurganya datang ke Mapolres Cirebon untuk melaporkan kejadian tersebut. Laporan tersebut langsung ditindaklanjuti, dan pada Minggu (16/12) pelaku diamankan di Alunalun Palimanan saat sedang berjualan sandal. Dapat diketahui bahwa maksud dari kata dikerjai dalam kalimat (26) adalah diperkosa. Dalam lingkungan masyarakat, perkosa merupakan perbuatan kriminal yang sangat dianggap buruk dan keji. Sehingga korban dari perbuatan tersebut pun dianggap buruk dan menjadi aib tersendiri, terlebih jika korban sampai hamil. Dari pemaparan berita tersebut, dapat diketahui bahwa kata dikerjai memilikinilai rasa lebih ramah dari kata diperkosa.

\section{(27) Di Ciwaringin, Polisi Sergap Wanita yang Diduga Jual Mihol}

Kalimat (27) terdapat dalam berita yang berjudul Sasar Pengendara dan Penjual Miras, yang terbit pada 7 Januari 2019. Kata wanita dalam kalimat tersebut mengalami perubahan makna ameliorasi. Kata wanita merupakan sinonim dari perempuan. Dalam KBBI, perempuan berarti 'orang (manusia) yang memiliki vagina, dapat menstruasi, hamil, melahirkan anak, dan menyusui; wanita'. Walaupun kata wanita dan perempuan memiliki makna yang sama, namun keduanya memiliki nilai rasa yang berbeda. Dalam kajian ilmu semantik, yaitu ilmu yang mengkaji tentang makna kata, kata wanita dikatakan memiliki nilai rasa yang lebih tinggi (konotasi baik) dari perempuan. Hal tersebut dikarenakan sebutan wanita adalah untuk perempuan yang berpendidikan lebih dan modern dalam segala.

(35) Sumber yang merupakan PNS di Pemkab Cirebon itu bahwa semua yang diperiksa KPK tidak semua berasal dari unsur PNS.

Kalimat (35) terdapat dalam berita yang berjudul KPK Periksa 48 Orang Di Cirebon, yang terbit pada 14 Januari 2019. Kata diperiksa dalam kalimat tersebut telah mengalami perubahan makna bentuk ameliorasi. Kata diperiksa pada kalimat tersebut, dapat diartikan sebagai diinterogasi. Hal tersebut dapat diketahui berdasarkan konteks kalimatnya. Dalam berita tersebut, diungkap pemeriksaan yang dilakukan oleh KPK terhadap 48 orang di Cirebon terkait kasus Sunjaya tentang jual beli jabatan, perizinan dan fee proyek. Pemeriksaan dilakukan di Mapolres Cirebon Kota (ciko) secara bergiliran. Hari Senin (14/1) ada 16 orang yang diperiksa, Selasa (15/1) sebanyak 14 orang, Rabu (16/1) 14 orang lagi, sisanya Kamis (17/1) dan Jumat (18/1). Pemeriksaan yang dilakukan pada hari Senin hingga Rabu yang diperiksa adalah PNS, honorer, dan pensiunan, sementara Kamis dan Jumat giliran para pengusaha untuk menjalani pemeriksaan.

Berdasarkan pemaparan berita di atas, dapat diketahui bahwa maksud dari kata diperiksa adalah diinterogasi. Jika dalam bidang kesehatan pemeriksaan berkaitan dengan pemeriksaan dokter terhadap pasien untuk mengetahui gejala penyakitnya, maka dalam bidang kriminal kata pemeriksaan dimaksudkan diinterogasi lebih lanjut untuk dimintai keterangan terkait kasus kriminal tersebut. Kata diperiksa memiliki nilai rasa lebih baikdari kata diinterogasi. Hal tersebut dikarenakan kata diinterogasi penggunannya berkaitan dengan hal-hal negatif. 
(43) Gagal Nyabu, Gagal Ngamar.

Kalimat (43) terdapat dalam berita yang berjudul Tadi Malam Satpol PP Razia Esek-esek, yang terbit pada 29 Januari 2019. Kata ngamar dalam kalimat tersebut, telah mengalami perubahan makna ameliorasi. Kata ngamar dalam kalimat tersebut merupakan bentuk kias dari kata ngeseks. Hal tersebut dapat diketahui berdasarkan konteks kalimatnya. Dalam berita tersebut, diungkap seorang pria yang berinisial PN (45) digelandang polisi pada Rabu malam (9/1) sekitar pukul 19.00 Wib di penginapan Desa Sutawinangun, Kecamatan Kedawung Kabupaten Cirebon. Bermula saat polisi melaksanakan operasi rutin di sekitar wilayah Kedawung, tiba-tiba ada laporan dari masyarakat tentang keberadaan orang yang mencurigakan di salah satu penginapan di wilayah Desa Sutamangun. Setelahnya, polisi pun langsung menindaklanjuti laporan tersebut.

Benar saja, saat di lokasi polisi melakukan investigasi di wilayah Desa Sutamangun polisi mencurigai gerak-gerik seorang pria yang berinisial PN (45) yang hendak masuk kamar hotel. Polisi langsung melakukan pemeriksaan pada pria tersebut. Dari hasil pemeriksaan, PN tertangkap tangan memiliki narkoba jenis sabu-sabu sebanyak dua paket dibungkus dengan plastik klip bening yang disembunyikan di saku celana bagian depan. Selain itu, polisi juga menyita alat hisap sabu dan $H P$ pelaku sebagai barang bukti. Saat dilakukan pemeriksaan lebih lanjut di kantor Satnarkoba Polres Cirebon, tersangka mengaku akan menggunakan sabu bersama teman perempuannya di kamar hotel. Pelaku berniat pesta sabu dan seks bersama teman perempuannya tersebut. Saat ditesurin, pelaku terbukti menggunakan narkotika jenis sabu-sabu. Akibat dari perbuatannya, pelaku dijerat pasal 112 ayat (1) jo pasal 114 ayat (1) jo pasal 127 UU RI Tahun 2009 tentang Narkotika.

Dari uraian berita di atas, dapat diketahui bahwa maksud dari kata ngamar adalah ngeseks. Diungkapkan dalam berita bahwa pelaku akan melakukan pesta sabu dan seks bersama teman perempuannya di hotel. Kata $n g a-$ mar memiliki nilai rasa lebih ramah (konotasi baik) dari kata ngeseks. Hal tersebut dikarena- kan kata ngamar merupakan bentuk kias dari maksud sebenarnya yaitu ngeseks.

\section{Fator Penyebab Perubahan Makna Peyorasi dan Ameliorasi}

Faktor-faktor yang menjadi penyebab perubahan makna bentuk kata dan frasa dari dalam ini adalah sebagai berikut.

Pertama, perkembangan sosial dan budaya. Contoh-contoh kalimat berikut ini menjelaskan fenomena perubahan makna karena perkembangan sosial dan budaya.

\section{(27) Di Ciwaringin, Polisi Sergap Wanita yang Diduga Jual Mihol \\ Faktor penyebab kata wanita memiliki} nilai rasa lebih tinggi (baik) dari kata perempuan adalah karena perkembangan sosial dan budaya. Perkembangan sosial dan budaya memaksa manusia untuk mampu menjadi berkembang dan modern mengikuti zaman. Dan wanita merupakan sosok perempuan dewasa yang berpendidikan lebih dan modern dalam segala hal mengikuti perkembangan zaman. Berbeda dengan perempuan biasa yang pendidikannya kurang dan kurang modern dalam segala hal. Oleh karena itulah, kata wanita memiliki nilai rasa lebih tinggi daripada kata perempuan.

(40) EK, pria asal Ciroyon, Bandung terpaksa harus mendekam di balik jeruji Mapolsek Plered lantaran sepeda motor Scoopy nopol E 5083 IP milik pedagang es tebu.

Faktor penyebab kata pria memiliki nilai rasa lebih tinggi (baik) dibandingkan kata laki-laki adalah karena perkembangan sosial dan budaya. Sebelum kemerdekaan, laki-laki merupakan julukan bagi orang yang memiliki status sosial yang tinggi. Akan tetapi, akibat perkembangan sosial dan budaya, pria dikatakan lebih tinggi dari laki-laki dalam status penggunaanya. Hal tersebut dikarenakan pria merupakan laki-laki dewasa yang memiliki pendidikan lebih dan modern dalam segalanya, seeprti halnya wanita.

Kedua, perbedaan bidang pemakaian. Perubahan makna karena perbedaan bidang pemakaian tampak pada contoh-contoh kalimat berikut. 
(35) Sumber yang merupakan PNS di Pemkab Cirebon itu bahwa semua yang diper$i k s a$ KPK tidak semua berasal dari unsur PNS.

Faktor penyebab makna kata diperiksa memiliki konotasi lebih ramah dari kata diinterogasi adalah karena adanya perbedaan bidang pemakaian. Kata diperiksa merupakan istilah dalam bidang kesehatan yang kemudian digunakan dalam istilah kriminal. Dalam istilah kesehatan, diperiksa merupakan proses pasien yang di cek kondisi kesehatannya oleh dokter untuk mengetahui kondisi pasien tersebut. Sementara dalam bidang kriminal, pemeriksaan merupakan proses pengecekan yang dilakukan polisi terhadap tersangka atau pelaku kejahatan untuk dimintai keterangan lebih lanjut tentang tindak kriminal yang dilakukan. Dalam bidang kriminal hal tersebut disebut dengan istilah diinterogasi. Akan tetapi, kata pemeriksaan kemudian digunakan juga dalam bidang kriminal guna mengkiaskan maksud yang sebenarnya yaitu interogasi yang memiliki makna buruk. Oleh karena itulah kata pemeriksaan dalam bidang kriminal memiliki nilai rasa yang lebihbaik dari kata interogasi.

Ketiga, adanya asosiasi. Perubahan makna adanya asosiasi tampak pada contohcontoh kalimat berikut.

(28) Saya kembali menghubungi kontak-kontak kupu-kupu ini.

Faktor penyebab makna kata kupuкири memiliki nilai rasa lebih baik dari kata pelacur adalah karena adanya asosiasi. Asosiasi yang berupa bentuk kias dari maksud sebenarnya yaitu pelacur. Asosiasi antara kupu-kupu (lengkap kupu-kupu malam) dengan pelacur adalah berkenaan dengan wanita pekerja seks komersial.

\section{(43) Gagal Nyabu, Gagal Ngamar.}

Faktor penyebab makna kata ngamar memiliki nilai rasa lebih ramah dari kata $n g$ eseks adalah karena adanya asosiasi. Asosiasi yang berupa bentuk kias dari maksud sebenarnya yaitu ngeseks. Asosiasi antara ngamar dan ngeseks adalah berkenaan dengan hubungan intim yang dilakukan oleh laki-laki dan perempuan.
Keempat, perbedaan tanggapan. Perubahan makna perbedaan tanggapan tampak pada contoh-contoh kalimat berikut.

(23) KPK berhasil mengamankan sejumlah dokumen, sebuah laptop dan dua buah CPU.

Faktor penyebab makna kata mengamankan memiliki konotasi lebih baik dari kata menyita adalah karena adanya perbedaan tanggapan. Perbedaan tanggapan baik buruknya nilai rasa dari penggunaan suatu kata tersebutlah yang kemudian menyebabkan terjadinya perubahan makna.

\section{(26) “Dikerjai" Pedagang Pasar Malam}

Faktor penyebab makna kata dikerjai memiliki nilai rasa lebih ramah dari kata diperkosa adalah karena adanya perbedaan tanggapan. Perbedaan tanggapan tentang penggunaan kata dikerjai memiliki nilai rasa lebih baik dari kata diperkosa. Baik buruknya nilai rasa dari penggunaan suatu kata tersebutlah yang kemudian menyebabkan terjadinya perubahan makna.

(14) Tiga hari penyelidikan, akhirnya jejak keberadaan pelaku terendus.

Faktor penyebab makna kata terendus memiliki konotasi lebih buruk dari kata diketahui adalah karena adanya perbedaan tanggapan. Perbedaan tanggapan mengenai baik dan buruknya nilai rasa dari penggunaan suatu kata tersebutlah yang dapat menyebabkan terjadinya perubahan makna.

\section{(19) Pelaku Curanmor Diamuk Massa.}

Faktor penyebab makna kata diamuk memiliki nilai rasa lebih buruk dari kata dihaki$m i$ adalah karena adanya perbedaan tanggapan. Perbedaan tanggapan mengenali penggunaan kata diamuk yang memiliki nilai rasa lebih buruk dari kata dihakimi. Perbedaan baik buruk tersebutlah yang kemudian menyebabkan perubahan makna kata mengalami perubahan.

(23) Dari kasus ini baru sunjaya dan gatot yang akhirnya jadi pesakitan.

Faktor penyebab makna kata pesakitan memiliki konotasi lebih buruk dari kata pelaku 
adalah karena perbedaan tanggapan. Perbedaan tanggapan tentang penggunaan kata pesakitan yang memiliki nilai rasa lebih buruk dari kata pelaku. Perbedaan baik dan buruknya nilai rasa dari penggunaan kata tersebutlah yang menyebabkan terjadinya perubahan makna.

\section{SIMPULAN}

Hasil penelitian yang bersumber dari berita kriminal pada surat kabar Radar Cirebon edisi Januari 2019, diperoleh bentuk perubahan makna peyorasi dan ameliorasi yang berupa kata dan frasa. Selain itu, diketahui faktor penyebab perubahan makna bentuk peyorasi dan ameliorasi dari data tersebut meliputi faktor perkembangan sosial dan budaya yang dialami 2 bentuk kata amelorasi, faktor perbedaan bidang pemakaian yang dialami 1 bentuk kata, faktor adanya asosiasi yang dialami 2 bentuk kata, serta faktor perbedaan tanggapan yang dialami oleh 37 bentuk kata dan 7 bentuk frasa.

\section{DAFTAR PUSTAKA}

Chaer, A. (2013). Pengantar Semantik. Jakarta: Rineka Cipta.
Dewi, M. (2013). Pengaruh Tayangan Berita Kriminal di Televisi terhadap Kecemasan Ibu Rumah Tangga akan Tindak Kejahatan Anak di Samarinda. Ilmu Komunikasi, 1(4), 150-162.

Hasanah, N. (2018). Analisis Kesalahan Gramatika Bahasa Indonesia dalam Surat Resmi di Kantor Desa Mamben Lauk. Prasasti: Journal of Linguistic, vol 4, no(35), 98-112. https://doi.org/ http://dx.doi.org/10.20961/prasasti. v3i1.2064

Kustriyono, E. (2016). Perubahan Makna dan Faktor Penyebab Perubahan Makna dalam Media Cetak. Bahastra, 37(2), 13-25. https://doi.org/http://dx.doi. org $/ 10.26555$

Moleong, L. J. (2013). Metode Penelitian Kualitatif. Bandung: PT Remaja Rosdakarya.

Pateda, M. (2010). Semantik Leksikal. Jakarta: Rineka Cipta.

Sugiyono. (2014). Memahami Penelitian Kualitatif. Bandung: CV Alfabeta. 